\title{
The Influence of Electronic Word-of-Mouth Communication on the Behaviour of the Theatre Audience Analysed Through the Kosovo Example
}

\author{
Shpresë Mulliqi \\ PhD Cand. University of Prishtina
}

\begin{abstract}
The expansion of Internet, the development of the new information and communication technologies as well as social networks have revolutionized the social interaction as they have enabled individuals to quickly and conveniently get in touch with each other. The interaction performed online, defined as online interpersonal communication, or the Electronic word-of-mouth (eWOM), as seen in numerous research papers, impacted the consumer behaviour. This paper analyses audience behaviour when making decisions vis-à-vis cultural offers presented in social networks. Although the issue of subjectivity in relation to the offered content in these platforms is set up as a determining factor for using e-WoM and the social networks, the main results suggest that both have been used by audience as a primary source of information when deciding to visit a cultural event. Moreover social networks have been described as places where information is not headed by clienteles, thus significant, customer friendly and trustworthy, despite the fact that all these information are based on subjective impressions of each social network user. The limited number of research on the impact of online communication of the theatre audience has been perceived as an obstacle, as there are no guiding direction how we should do it, and as a challenge, given that through this research we will set the baseline for future researches that will analyse the effectiveness of eWoM.
\end{abstract}

Keywords: e-WoM, social networks, Internet, Information and communication technology, costumers, theatre.

\section{Introduction}

"Audience development is not just about people who come to the arts. It's also about people who don't come."

Richard Hadley, Director, Audiences Europe Network

During the '90, Kosovo, especially Albanian population', has experienced media blackout; no electronic media operated in Kosovo for a decade, and the only national television, Radio Televizioni i Prishtinës ${ }^{2}$ (RTP) has fulfilled information needs of only one part of the Kosovo population ${ }^{3}$. During this period Albanian print media have been closed several times, as they took the role of the only source of information ${ }^{4}$. As a result most of the information have been shared through the word-ofmouth (i.e., face-to-face and/or through the telephone conversations), which played a great role in all spheres of life, though its impact significantly was determined by the persuading abilities of a person conveying the message ${ }^{5}$. The persuasive

\footnotetext{
${ }_{1}^{1}$ According to the statistics comprised Albanian population represented $81.6 \%$ of Kosovo population. Enti i Statistikës së Kosovës, for more information visit the official web page of the Kosovo Agency of statistics; http://ask.rks-gov.net/

2 Radio Television of Prishtina, or RTP, the first Albanian Radio Television of Kosovo was established in 1945after the World War II. The broadcasting of this television program was interrupted by the violent actions of the Serbian government in 1990. By Ibrahim Berisha, Komunikimi medial në shoqërinë postkonfliktuale; extracted from the Thesis Kosova, nr. 1, 2008 https://aabedu.net/downloads/01_2008_07_ibrah_jnaDQ.pdf

3 It has fulfilled the information needs of Serbs, who represented $9.9 \%$ of Kosovo population and $8.5 \%$ per cent of "other nationalities" including Yugoslavs and non-declared.

${ }^{4}$ Biggins, M. and J. Crayne, (2000) Publishing in Yugoslavia's Successor States, The Haworth Information Press, An Imprint of The Haworth Press, Inc. New York, USA; Volume 1, Numbers 2/3. Pg. 162 - 163

${ }^{5}$ Krauss, R. M. (1987). The role of the listener: Addressee influences on message formulation. Journal of Language and Social Psychology, 6, 81-97.
} 
significance of the word of mouth, a set of artistic proofs which are controlled by the speaker ${ }^{1}$, has had a major impact on what people knew, felt and have done during the media blackout days in Kosovo.

Theatre survived the media blackout of nineties. The number of visitors of theatre kept on increasing regardless the fact that no marketing tools have been used in order to attract audience. We cannot document this period ${ }^{2}$ as the data obtained from the official web page of the National Theatre of $\mathrm{Kosovo}^{3}$, cover only the period until 1989 when theater had over 400 premieres with about 10,000 reruns followed by over 3.3 million spectators ${ }^{4}$. As a result and in order to document the impact of word of mouth on theatre we had to rely on the information assembled through the interviews with artists and art critics, who conveyed the message that the word of mouth and print media played a great role in audience development, which, according to the findings of the conference "European Audiences 2020 and beyond", is very important ${ }^{5}$, should we want to maintain qualitative theatre to be resulted in the increased number of audience.

In 1999 Kosovo has been enriched with print and electronic media whereas the penetration of the Internet ${ }^{6}$ and the Information Communication Technology (ICT) in Kosovo slowly started its development. From being almost non-existent 16 years ago, Kosovo IT companies started offering wide range of ICT services to their customers ${ }^{7}$, which has transformed the communication channels from the word of mouth to computer-mediated communication ${ }^{8}$, a process during which people meet and develop relationships relying on typed messages, or the Electronic word-of-mouth (eWOM), as a primary mechanism of expression? ${ }^{9}$.

The new media technology, developed to ease this communication, plays a significant role as it offers new ways to achieve efficient distribution of messages, by enabling direct and interactive communication at a very low $\operatorname{cost}^{10}$, promotion of new offers as well as advertising and enhancement of offer ${ }^{11}$. Given the significance of this new way of communication, already embraced by various establishments, the cultural institutions in Kosovo, have started using these communication tools to share relevant information to the potential customers in order to increase the number of audience ${ }^{12}$. Therefore, the e-

\footnotetext{
1 Steinberg, S., (1999). Persuasive Communication Skills: Public Speaking, Cape town : Juta Co and Pvt Ltd.

2 There are no data covering the period from 1990 until 1999, as the NTK, administered by the state, was closed for most of the Albanian workers, artists and the visitors .

${ }^{3} \mathrm{http}: / / w w w . t e a t r i k o m b e t a r . e u / ? \mathrm{~m}=\mathrm{t} \& \mathrm{id}=4$

${ }^{4}$ Official web page of the National Theatre of Kosova; $h$ ttp://www.teatrikombetar.info/al/perne/1/

${ }^{5}$ European Audiences: 2020 and beyond was held from 16 - 17 October 2012; Conference conclusions; http://ec.europa.eu/culture/library/reports/conference-audience_en.pdf

${ }^{6}$ According to the 2013 report on Internet Penetration and Usage in Kosovo, of the Kosovo Association of Information and Communication Technology (STIKK), internet penetration across the country is comparable to global norms. Internet penetration based on users is $76.6 \%$, and based on households is $84.8 \%$. http://www.mfa-ks.net/repository/docs/STIKK_raport_eng_2013_short_web.pdf. According to the Internet World Statistics as of Dec 31/14, Kosovo counts 1,523,373 Internet users, whereas the penetration rate is 80.9\%; http://www.internetworldstats.com/europa2.htm; Accessed in December 2016.

7 IT Barometer 2015 Kosovo; Published by The Kosovo Association of Information and Communication Technology (STIKK); http://stikk.org/fileadmin/user_upload/it_barometer_kosovo-2015_ang_1_.pdf. Last visited in December 2016.

8 The most interesting aspect of the advent of computer-mediated communication (CMC) is how it reveals basic elements of interpersonal communication, bringing into focus fundamental processes that occur as people meet and develop relationships relying on typed messages as the primary mechanism of expression.

https://pdfs.semanticscholar.org/7445/be9f99267248664b1c568a096e81b741c586.pdf

9 Walther, J. B. (1996). Computer-mediated communication: Impersonal, interpersonal, and hyper personal interaction. Communication Research, 23, 3-43.

${ }^{10}$ Cockrum, J., (2011). "Free Marketing: 101 Low and No-Cost Ways to Grow Your Business, Online and Off'; Published by John Wiley \& Sons, Inc., Hoboken, New Jersey, Page 97.

${ }^{11}$ Interview with Haqif Mulliqi, former Head of the Board of the National Theatre Kosovo, interviewed by Shpresë Mulliqi, 01.07.2016

${ }^{12}$ Hence now, all of them are open for wider public through the Internet based Web pages: National Theatre:

http://www.teatrikombetar.eu/?m=t\&id=4, Kosovo Ballet: http://www.baletikosoves.com/, Ensemble "Shota":

http://www.ansamblishota.org/al/index.php?p=0, National Gallery: http://www.galeriakombetare.com/, Cinematographic Centre of Kosova: www.qkk-rks.com; The institutional accounts on social networks and in Youtube: https://www.facebook.com/Teatri-Kombëtar-iKosovës-525429354192045/, https:/www.facebook.com/BaletiKombetariKosoves, https://www.facebook.com/pages/Filharmonia-EKosoves/506386249406854?fref=ts, https://www.facebook.com/Galeria.e.Arteve.e.Kosoves, https://www.facebook.com/Galeria.MKRS, https://twitter.com/QKK_Kosova, https://www.facebook.com/QKK-Qendra-Kinematografike-e-Kosoves-120072128088984/.
} 
Culture, defined as an application of information communication technologies on the culture industry ${ }^{1}$, has significantly affected the operational management of cultural institutions such as theatre, as well as other fields of operation of cultural institutions.

The objective of this paper is to analyse the power of the eWoM and its impact on the audience when making decisions vis-à-vis theatre offers. With the goal to support theatre in its struggle to return the audience in theatre, the research enabled us to gather and analyse relevant information, in order to define how the visitors of the National Theatre of Kosovo use the social networks during the decision-making process.

\section{The background of the research}

National Theatre of Kosova is struggling to get its audience back as well as to motivate the new ones to become regular visitors. The persistent problem has been discussed by the management, media and the civil society but no research has been done so fare to assess what triggered the audience parting from theatre nor has been looked for the ways to invite the audience. Meantime the National Theatre of Kosova is still using the traditional marketing channels like announcements, commercials and posters to reach the audience, which is getting the largest share of marketing budget, but it is less investing and doing minimum related to the online activities such as advertising on official website and eWoM supported by social networks, which according to the European Theatre Convention are getting more importance ${ }^{2}$ as they are based on the need of audience for reliable and neutral information.

Based on statistics Kosovo has 1,080,038 Internet users of age 10-60, a population that is very much active on social networks. The Kosovo Association of Information and Communication Technology report specifies that,

Emailing, Facebook, Skype and Youtube are the main services that are used in Kosovo; That $73.3 \%$ of Internet users use the Facebook service, which shows that $73.3 \%$ of $76.6 \%$ of Internet users are Facebook users - meaning that $43.6 \%$ (approximately 790000) of Kosovo's total population uses the Facebook service ${ }^{3}$.

Having that in mind the impact of word of mouth on Kosovo culture, and based on the international researches which emphasise the fact that the emerge of new media, has made customers more engaged in finding effective and reliable way to communicate and to find information, through this research we have analysed costumer's behaviour in Kosovo when searching information related to theatre events. As the information derive directly from the audience and are not provided by the theatre, the use of social networks to collect information and post them for community consumption as well as the impact of the eWoM have been evaluated, considering that these are more customer oriented information and thus better accepted $^{4}$.

With the aim of getting relevant data we have visited three theatre performances, the most visited ones, in order to find out what motivated the audience (as it appeared that the National Theatre hasn't done more for one performance than the other). Our research has been based on the study Digital audiences: Engagement with arts and culture online ${ }^{5}$, which states that customers search for sources of information which are easy to access, such as the online platforms, which enable visitors to share their thoughts, opinions and experiences. ${ }^{6}$

\footnotetext{
${ }^{1}$ CULTURELINK, Network of Networks for Research and Co-operation in Cultural Development was Established by UNESCO and the Council of Europe in 1989; eCulture: The European Perspective; Cultural Policy, Creative Industries, Information Lag; Proceedings from the Round Table Meeting, Zagreb, 24 - 27 April 2003; Instritute for International Relations, Zagreb, 2005

${ }^{2}$ Audiences for European Theatre, Study on the Status Quo of Audience Development and Audience Research in the European Theatre Convention, 2014

${ }^{3}$ http://www.mfa-ks.net/repository/docs/STIKK_raport_eng_2013_short_web.pdf. Accessed in December 2016.

${ }^{4}$ Audiences for European Theatre.

5 Digital audiences: Engagement with arts and culture online; Retrieved from the http://www.aandbscotland.org.uk/documents/2012-0528-13-11-39-10-Digital-audiences-for-arts-and-culture-november2010.pdf

${ }^{6}$ Digital audiences: Engagement with arts and culture online; Finding information about arts and culture online

When asked 'How do you go about finding new arts and culture related websites?' the vast majority (85\%) selected the response 'Google': 'If you've got a computer, it's the easiest way to find out what's on' $45-65$ year old $1 \%$ of respondents mentioned a range of alternative providers such as Yahoo, Ask.com and Bing. Recommendations from friends or family were the second most common route for discovering arts and culture related websites (37\%), which (like Google) is consistent across all subgroups of the sample.
} 
The relevance to the research subject

Understanding customer behaviour forms the basis for developing successful marketing strategies ${ }^{1}$ the behaviour of the theatre audience is a field which is not analysed in Kosovo. It has been acknowledged that it contributes to the financial wellbeing of the theatre but there is still much to be done in order to understand the way customers behave ${ }^{2}$ and how can be motivated by the management of the company. It is obvious that with the constant technological advancement customers are changing their behaviour patterns looking for more "customer-friendly" sources of information such as Facebook, Instagram, YouTube ${ }^{3}$ which are replacing the old-fashioned word of mouth.

We have selected National Theatre of Kosovo and individuals making decisions about the use of their available resources (time, money and effort) ${ }^{4}$ by considering its complexity and in order to understand customer behaviour vis-a-vi theatre. This selection has been done due to the fact that theatre product is not a simple item, goods or service of consumption, theatre is a set of activities that constitute experiences. The theatre product-the performance, cannot be verified prior to the "consumption"-watching; performance is done by people and that implies that it is not possible to obtain two products/performances alike and the product is produced and consumed at the very same time, in a simultaneous way. Due to all the particularities and unique characteristics of the theatre product, customers develop a special behaviour in their decision making process, which is very often conditioned by the word of mouth.

Typologies of the costumers and the complexity of audience behaviour in decision-making process

During the research process, researcher has come across the three types of customers; the constant customers who visit theatre on the premiere of the performance, prior to any feedback or any information. These costumers belong to an institutionalized type of visitors who get informed by the theatre about the products, through the old, and so called well established, marketing tools such as TV ads and posters in front of the theatre.

The second type of visitors the researcher came across are hesitant customers, similar to the constant customer, however this one is hesitant in making his/her decision and wishes to participate more in the process. This type of customer gets informed through the theatre but searches for additional information by getting in contact with producers or actors.

The third type of visitors the researcher came across are the costumers who get informed through the social networks, through the so called computer-mediated communication, which replaces the traditionally well-established communication through the word of mouth. They make their plans based on the information obtained through the eWoM.

While writing about the findings of this research we had to keep in mind the fact that results might change within months as every person goes through the changes in life, depending on which they will change from one typology to another.

Methodology of the research

According to the European Theatre Convention empirical evidence about situation and audiences of theatres in Europe so far has been rather heterogeneous. ${ }^{5}$ According to the ETC in a number of countries, including Kosovo, there is no such information. Hence the lack of comparable data on National Theatre of Kosovo and its audience was a major challenge when outlining new tools and measures for audience development. In the given situation we had to rely on the information obtained from the institution, which was done through the interviews. The outlined information related to the behaviour of the customers of national theatre shall serve as a point of reference.

In order to perform the study and to identify costumer visiting patterns we have looked into the theatre offer: the genres of the performances and how many performances they show. ${ }^{6}$ According to the managerial director the total number of visitors

\footnotetext{
${ }^{1}$ Michael J. Papa, Tom D. Daniels, Barry K. Spiker, (2009). Organizational Communication Approaches and Trends-UET Press, p. 14

2 Blackwell, L.D., Miniard, P.W. and Engel, J.F., (2006). Costumer behavior. 10th ed. Mason: Thomson Business and Economics.

3 Based on the statistics of the Internet World Stats Kosovo has 860,000 Facebook users on Jun 30/16, and 45.7\% penetration

rate.Retrieved from the http://www.internetworldstats.com/europa2.htm; Accessed in December 2016.

${ }^{4}$ Schiffman, L. G. and Kanuk, L. L., (2010) Consumer behaviour. Global Edition. London. Pearson Higher Education.

${ }^{5}$ Retrieved from the Official Web page of the European Theatre Convention; http://www.etc-cte.org/index.php

${ }^{6}$ According to the Managerial Director of National Theatre of Kosova in their repertoire they have 8 productions per annum, with 234 performances. Interview with Valdet Avdiu, former director of the National Theatre of Kosova; interviewed by Shpresë Mulliqi, 01.08.2016.
} 
in 2015 is 17447, out of which 93 percent are inhabitants of Prishtina ${ }^{1}$ whereas 15 percent are from the region. The interviewed persons in this research are not selected at random; they are selected on purpose in order to satisfy the focus of this study. Thus, fifty (50) persons have been selected; among each generation, people are selected by gender: 23 men and 27 women in order to create a wider perspective. In addition, the entire sample has been selected according the completion of three criteria. Participants of the sample had to be: Frequent visitors of the theatre, active internet users and users of the internet as a main source of information when planning their visits to theatre and other cultural institutions.

Interviewed persons are of the different age groups: from 19 to 30 years (29 persons or $58 \%$ ), from 31 to 41 (9 persons or $18 \%$ ), from 42 to 51 ( 3 persons or $6 \%$ ), from 52 to 61 (6 persons or $12 \%$ ) and from 62 to 72 (3 persons or $6 \%$ ), as it is considered a good sample in order to get reliable information and also due to the fact that they are familiar with old marketing tools (posters, outdoor announcements, etc.) as well as with the new media, namely internet and social platforms.

In order to find the required participants, researcher has visited three performances, the most visited ones, and selected persons who fulfilled required criteria such as the costumers type, age, gender and the place they come from, which was not an easy task due to the hesitance encountered when explaining the purpose of the research. Researcher has also used the Facebook account of the National Theatre in order to find and contact people, followers of the National Theatre, for the interviews.

\section{Results of research on the role of social networks and the development of theater customer through the eWoM}

Questionnaire and the interview results suggest that eWord-of-mouth and computer mediated communications have more influence on customers than any other type of communication ${ }^{2}$. The research shows that consumers do not use only the information prepared by the marketing departments, but the unbiased information that come through the Internet before making decision. These are the information distributed through the social networks, experiences shared through the eWoM, photographs, and uploaded videos. According to the results customers need to get firsthand information from reliable sources as they believe that these are non-clienteles driven information and do not imply any type of monetary refund. The research to e certain extend confirms authors saying that the eWord-of-mouth is one of the most powerful forces on the marketplace (Silverman, 2001 p. 23).

On the other hand, as we have focused our research on three generations, we have encountered some differences. Users of Internet and social networks, persons of age between 19 to 30 and 31 to 41 , which represent $38 \%$ of the respondents, are the regular customers as well as active information seekers of all generations. They are experienced to search and find online information. According to the interviewees they find the information on the internet and social newtorks in several ways; some information are placed by actors, interested to let the public know that they are engaged in a theatre project, some information are placed by the director or the writer of the theatre play but most of information are placed by customers, the theatre audience. However, at this point the interviewees have also raised the questions related to the subjectivity and the credibility when information placed by those actively involved in production, though they admitted that these information are used as a valid reference for further search.

In regards to the interviewees of the age from 42 to 51 , which represent $6 \%$ of respondents, they do not use social networks as frequently as the other generations. In spite of that, when deciding to go to the theatre they also are influenced by the eWoM. In this case they look for user friendly web pages and internet based media. Channel for information about the production used at large, according to the interviewees, are: YouTube 14,4 (<5\%) and Twitter 15,4 (<5\%), Facebook namely the Facebook page of the theatre 9,8 (ca. 10\%) and the WoM (Partners / friends / associates / relatives 1,4 (ca. $40 \%)$.

It is interesting that the interviewees of age 52 to 61 and of the age 62 to 72 are the one that most of the information gets from the old fashioned marketing tools; they together make $18 \%$ of respondents. Information placed on social media is a reference but the first sources of information billboards and outdoor posters. Although the issue of subjectivity in relation to the offered content in these platforms is set up as a determining factor for using social networks, the main results suggest that the customers trust the eWoM when deciding to visit a cultural events as the information is not headed by clienteles,

\footnotetext{
1 The National Theatre of Kosovo is located in Prishtina, the Capital city of Kosova.

2 Herr, P. M., Kardes, F. R., and Kim, J, (1991) Effects of Word-of=Mouth and Product-Attribute Information on Persuasion: An Accessibility-Diagnosticity Perspective, Journal of Consumer Research, 17 (4).
} 
thus significant, customer friendly and trustworthy, despite the fact that all these information are based on subjective impressions of each social network user.

The groups of interviewees who prefer old marketing and information tools state that certain reviews are perceived as false; therefore question of credibility must be examined.

\section{Conclusions}

eWord of Mouth spread through the social networks has an impact on the behaviour of theatre costumers. Social networks offer customers the opportunity to express themselves, share contents, ideas and experiences which other customers may use as a reference in their planning; fact which is greatly appreciated among customers due to the high needs of information which they require. The development of Internet and social networks has changed communication patterns drastically ${ }^{1}$, though cultural institutions, in our case theatre, still allocates a large share of marketing budget on standard print advertising and the production of classical own print media like programs, theatre newspapers etc.. Parallel, the majority of cultural institutions has installed the basic channels of digital communication and is offering user friendly social media, at least Facebook, though not frequently updated.

Social networks are searched and used all along the decision-making process for cultural products and by all generations of users. However, its use varies among the different stages of the process as well as among generations. In the prepurchase stages social media form the main source of information. Customers when searching for information are eager to read customers' experiences which are perceived as far from marketers' bias, user-friendly information, more credible and reliable and which offer a two-sided perspective. A wide number of platforms are used: forums, blogs and social networks for information hence it would be very interesting for cultural institutions to increase their presence through social media marketing strategies.

In spite of the wide use of social networks, questions concerning subjectivity and credibility might arise. Some reviews and opinions are perceived as false, therefore customers feel forced to carry out an evaluation process of the computer mediated information in order to find the truth behind those contents; this process might be time consuming and thus may persuade customers to turn less time consuming sources of information. In this point a great generational differences have been identified, while the youngest generation of users attribute more credibility and are more influenced by eWoM and the internet, other generations use internet and social media based information as complementary information rather than a determinant. In regards to the post event phase the eWoM is used for sharing personal experience whereas the social networks are used to share contents and upload information to friends' and online communities.

This study is a very first research done in order to understand correlation between the eWoM, the social networks and customer behaviour hence it should be used by the cultural institution for audience development. As Richard Hadley, the Director of the Audiences Europe Network has stated the Audience development is not just about people who come to the arts. It's also about people who don't come. The impact of internet and social networks confirmed by the interviewed customers implies that cultural institution should focus in developing a new communication strategy in order to attract them by providing them with the information they need and require.

\section{References:}

[1] Bailey, A.A. (2007) Public Information and Consumer Skepticism Effects on Celebrity Endorsements: Studies among Young Customers. Journal of Marketing Communications, 13 (2): 85 - 107, Routledge.

[2] Biggins, M. and J. Crayne, (2000) Publishing in Yugoslavia's Successor States, The Haworth Information Press, An Imprint of The Haworth Press, Inc. New York, USA; Volume 1, Numbers 2/3. Pg. 162 - 163

[3] Blackwell, Miniard and Engel (2006). Consumer Behavior (10th Ed.). Thomson Learning.

[4] Czaja, R. and Blair, J. (1996).Designing Surveys: A guide to decisions and procedures. Thousand Oaks, CA: Pine Forge Press. 
[5] Grove, S. J. and Fisk, R. P. (1992) ,"The Service Experience As Theater", in NA - Advances in Consumer Research Volume 19, eds. John F. Sherry, Jr. and Brian Sternthal, Provo, UT : Association for Consumer Research, Pages: 455-461.

[6] Herr, P.M., Kardes, F.R., and Kim, J., (1991); Effects of Word-of-Mouth and Product-Attribute Information on Persuasion: An Accessibility-Diagnosticity Perspective, Journal of Consumer Research, 17 (4).

[7] Hsieh, H.F. and Shanon, S.E. (2005). Three Approaches to Qualitative Content Analysis. Journal of Qualitative health research 15 (9) 1277-1288. Available from: http://qhr.sagepub.com, Accessed 13 October 2016

[8] http://www.aandbscotland.org.uk/documents/2012-05-28-13-11-39-10-Digital-audiences-for-arts-and-culturenovember2010.pdf, Accessed December 2016

[9] https://pdfs.semanticscholar.org/7445/be9f99267248664b1c568a096e81b741c586.pdf

[10] J. L.Borgerson, J.E.Schroeder (2005); Identity in Marketing Communications: An Ethics of Visual Representation. Marketing Communication: New Approaches, Technologies and Styles, Oxford University Press.

[11] J. Schmitz, J. Fulk (1991); Organizational colleagues, media richness, and electronic mail, Communication Research 18(4), pp. 487-523.

[12] Lee, A. (1994) Electronic mail as a medium for rich communication: an empirical investigation using hermeneutic interpretation, MIS Quarterly 18(2), pp.145-157.

[13] Lipnack, J., Stamp J. (1997); Virtual Teams: Reaching Across Space, Time and Organizations with Technology, John Wiley \& Sons, New York.

[14] Markus, L. (1994); Electronic mail as the medium for managerial choice, Organization Science 5, pp. 502-527.

[15] Morozan, Ch. (2011); Principles and Evolution of the Internet Marketing, Economic Sciences Series, Volume XI, Issue 1. Ovidius University; Available at www.ssrn.org.

[16] R.E. Rice, J. D'Ambra, E. More (1998); Cross-cultural comparison of organizational media evaluation and choice, Journal of Communication 48(3), pp. 3-26.

[17] Ronchi, A. M. (2009) eCulture, Cultural Content in the Digital Age, Springer-Verlag Berlin Heidelberg

[18] Shachaf P., Hara, N. (2007); Behavioral complexity theory of media selection: a proposed theory for global virtual teams. Journal of Information Science 33(1), pp. 63-74.

[19] Sproull, L. and Keisler, S. (1986); Reducing social context cues: electronic mail in organizational communication, Management Science 32(11), pp. 1492-1513.

[20] This research was commissioned by Arts Council England, in partnership with Museums, Libraries and Archives Council (MLA) and Arts \& Business. "Digital audiences: Engagement with arts and culture online";

[21] Trusov, M. \& Bucklin, E.R. \& Pawels, H.C. (2010); Effects of word of mouth versus Traditional Marketing, Findings from Internet Social Networking Site.

[22] Turban, E., Mclean, E. And Wetherbe, J. (2004); Information technology for management: transforming organizations in the digital economy. 4th ed. Chichester: Wiley.

[23] Walther, J. B., \& Carr, C. T. (2010). Internet interaction and intergroup dynamics: Problems and solutions in computer-mediated communication. In H. Giles, S. Reid, \& J. Harwood (Eds.), The dynamics of intergroup communication (pp. 209-220). New York: Peter Lang

[24] Walther, J.B. (2006); Selective self-presentation in computer-mediated communication: Hyperpersonal dimensions of technology, language, and cognition 